\title{
KARAKTERISTIK ES KRIM MENGGUNAKAN STARTER BAKTERI PROBIOTIK Streptococus thermophilus dan Lactobacillus acidophilus
}

\author{
Grace Bahow*, A. Yelnetty, M. Tamasoleng, W.J.H. Pontoh \\ Fakultas Peternakan Universitas Sam Ratulangi Manado, 95115
}

\begin{abstract}
ABSTRAK
Penelitian ini bertujuan untuk mengetahui pengaruh penggunaan bakteri probiotik, yakni Streptococus thermophilus dan Lactobacillus acidophilus sebagai starter terhadap karakteristik dan organoleptik es krim. Perlakuan tersebut adalah level starter yang berbeda, yaitu $\mathrm{A} 1=0 \%, \mathrm{~A} 2=3 \%, \mathrm{~A} 3=$ $6 \%$, dan $\mathrm{A} 4=9 \%$. Variabel penelitian adalah total bakteri asam laktat (BAL), $\mathrm{pH}$, dan overrun. Hasil penelitian menujukkan bahwa total BAL berkisar antara 1,49 - 7,08 ( $\log$ $\mathrm{cfu} / \mathrm{ml}), \mathrm{pH}$ berkisar antara 5,24-5,67, sedangkan overan berkisar antara 25,62$31,47 \%$. Hasil analisis ragam menunjukkan bahwa perlakuan level starter $0 \%, 3 \%, 6 \%$, dan $9 \%$ memberikan pengaruh yang berbeda sangat nyata $(\mathrm{P}<0,01)$ terhadap total bakteri asam laktat, $\mathrm{pH}, \mathrm{dan}$ overrun. Berdasarkan hasil penelitian yang dilakukan disimpulkan bahwa karakteristik es krim menggunakan starter Streptococus thermophilus dan Lactobacillus acidophilus pada level 9\% menghasilkan es krim terbaik secara uji fisik, dan mikrobiologis.
\end{abstract}

Kata Kunci : Bakteri probiotik, es krim, starter, total BAL, $\mathrm{pH}$, overrun.

\begin{abstract}
CHARACTERISTICS OF ICE CREAM USING STARTER OF PROBIOTIC BACTERIA Streptococus thermophilus and Lactobacillus acidophilus. This study aimed to determine the effect of the use of probiotic bacteria, namely Streptococcus thermophilus
\end{abstract}

\footnotetext{
*Korespondensi (corresponding author):

Email: grace.bahow@yahoo.com
}

and Lactobacillus acidophilus as a starter on the characteristics ice cream. This experiment was arranged in Completely Randomized Design, with four treatments and five replications. Such treatmentis the different levels of starter $\mathrm{A} 1=0 \%, \mathrm{~A} 2=3 \%, \mathrm{~A} 3=6 \%$, and $\mathrm{A} 4=9 \%$. Data were analized by variance analysis. The results of experiment showed that the total of lactic acid bacteria ranged from 1.49 to $7.08(\log \mathrm{cfu} / \mathrm{ml})$, the $\mathrm{pH}$ ranged from 5.24 to 5.67, while overrun ranged from 25.62 to $31.47 \%$. The Results of analysis showed that the starter level of $0 \%, 3 \%, 6 \%$ and $9 \%$ gave a highly significant effect ( $\mathrm{P}$ $<0.01$ ) on total of lactic acid bacteria, $\mathrm{pH}$, and overrun. The counclution of this research was ice cream using a starter streptococcus thermophilus and Lactobacillus acidophilus at the level of $9 \%$ is the best ice cream on physical, and microbiological test.

Key word: Probiotic bacteria, ice cream, starter, total of lactic acid bateria, $\mathrm{pH}$, overrun.

\section{PENDAHULUAN}

$$
\text { Seiring dengan meningkatnya }
$$
pengetahuan konsumen akan pangan yang sehat, maka masyarakat mulai memilih mengkonsumsi pangan yang tidak hanya dilihat dari rasa dan nilai gizi saja tetapi 
juga diperhatikan nilai tambah yang terdapat dalam pangan tersebut. Peningkatan pengetahuan konsumen terhadap makanan sehat menjadikan permintaan akan makanan fungsional juga mengalami peningkatan. Makanan fungsional (functional foods) merupakan makanan yang mengandung senyawa atau komponen bioaktif yang berguna untuk pencegahan penyakit serta dapat mempertahankan kesehatan konsumen secara optimal.

Salah satu jenis produk pangan kesehatan yang berkembang pesat adalah makanan probiotik dengan bermacam bentuk dan rasa yang melibatkan bakteri asam laktat dalam proses pembuatannya. Es krim probiotik merupakan es krim yang mengandung bakteri asam laktat yang berpotensi sebagai probiotik, yaitu mikroba hidup yang bila dikonsumsi dalam jumlah yang cukup akan meningkatkan kesehatan dengan cara memperbaiki keseimbangan mikroflora dalam usus (Fuller, 1999).

Es krim dapat didefinisikan sebagai makanan beku yang dibuat dari susu dan dikombinasikan dengan perasa dan pemanis. Pembuatan es krim secara umum menggunakan bahan dasar susu, gula, telur, dan bahan perasa seperti vanila, buah-buahan, coklat dan lain sebagainya. Es krim sering dikonsumsi sebagai makanan penutup, dengan rasa yang bervariasi seperti rasa coklat, vanilla, strawberi hingga rasa buah-buahan yang memberikan kesegran pada es krim. Konsumsi es krim meningkat dari waktu ke waktu ditandai dengan makin meningkatnya varian dan jumlah es krim di pasaran.

Bakteri probiotik bersifat dapat mengkolonisasi dalam saluran cerna dan memberikan efek positif bagi kesehatan, dengan menyeimbangkan pertumbuhan mikroorganisme dalam pencernaan (Gueimonde dan Gavilan, 2009).

Penggunaan bakteri probiotik dalam penelitian ini dimaksudkan guna peningkatan nilai tambah dari es krim yang dihasilkan. Dalam pembuatan es krim secara umum yang beredar dipasaran belum ditemui es krim yang menggunakan bakteri probiotik dan juga secara ilmiah penjelasan penggunaan bakteri probiotik pada pembuatan es krim masih jarang dilakukan di Indonesia. Efek probiotik bagi kesehatan konsumen yang mengkonsumsi produk probiotik dapat bersumber dari produksi asam-asam organik maupun bakteorisin yang dihasilkan oleh bakteri probiotik, yang dapat membunuh bakteri patogen serta meningkatkan sitim imun dalam tubuh (Chen dan Chen, 2007). Tujuan penelitian 
ini adalah untuk mengetahui karakteristik es krim menggunakan starter $S$. thermophilus dan L. acidophilus dengan level starter 3\%, 6\%, dan 9\%

\section{MATERI DAN METODE PENELITIAN}

Penelitian ini telah dilaksanakan pada tanggal 2 Februari 2015 sampai dengan tanggal 26 Maret 2015 di Laboratorium Teknologi Hasil Ternak, Fakultas Peternakan, Universitas Sam Ratulangi Manado.

Bahan yang digunakan adalah empat (4) liter susu UHT, 800 gram wheap cream, 600 gram gula pasir, delapan (8) butir kuning telur, 200 gram maizena, 800 gram susu bubuk putih, empat (4) bungkus agar dan air. Bakteri probiotik dalam bentuk starter yakni S.thermophilus dan L.acidophilus. Bahan analisa yang digunakan adalah media MRS agar, alkohol, buffer $\mathrm{pH}$ 4, larutan $\mathrm{NaOH} 0,1 \mathrm{~N}$, aquades, indikator fenolfatelin, pepton, water

Peralatan yang digunakan selama penelitian antara lain, lemari pendingin, autoclave, inkubator, timbangan, mixer, erlenmeyer, tabung reaksi, cawan petri, $\mathrm{pH}$ meter dan mikropipet.

Rancangan penelitian yang digunakan pada penelitian ini adalah rancangan acak lengkap (RAL) dengan perlakuan level starter S. thermophilus dan L. acidophilus $0 \%$, 3\%, 6\% dan 9\%, masing-masing perlakuan diulang sebanyak lima kali. Data yang diperoleh dianalisis menggunakan analisis varians, apabila terdapat perbedaan nyata antar perlakuan dilanjutkan dengan uji beda nyata jujur (Steel dan Torrie, 1991).

Variabel yang dianalisis pada penelitian ini adalah: analisis mikrobiologis (total BAL), $\mathrm{pH}$, overrun, dan organoleptik (warna, aroma, tekstur, dan cita rasa).

\section{Pembuatan Starter}

Pembuatan starter bakteri asam laktat yang akan digunakan mengacu pada metode Sofos et al. (1993). Sebelum penelitian dilakukan, semua peralatan yang akan digunakan disterilkan terlebih dahulu. Kemudian dilakukan pembuatan starter dari biakan bakteri Streptococcus thermophilus dan Lactobacillus acidophilus dengan cara larutan skim milk, gula, aquades disterilkan pada suhu $121^{\circ} \mathrm{C}$ selama 15 menit, kemudian didinginkan sehingga mencapai suhu $45^{\circ} \mathrm{C}$. Kemudian diinokulasi dengan biakan murni yang terdiri dari bakteri Streptococcus thermophilus dan Lactobacillus acidophilus dan diinkubasi pada suhu $36 \mathrm{C}$ selama 18 jam. 


\section{Pembuatan Es Krim Probiotik}

Proses pembuatan es krim probiotik mengacu pada penelitian yang telah dilakukan Yelnetty (2010) yaitu, susu UHT, dancow bubuk dan wheap cream di homogenisasi kemudian di pasteurisasi pada suhu $85^{\circ} \mathrm{C}$ selama 15 menit lalu didinginkan pada suhu $40^{\circ} \mathrm{C}$ kemudian di inokulasi dengan starter Streptococcus thermophilus dan Lactobacillus acidophilus, setelah itu diInkubasi pada suhu $40^{\circ} \mathrm{C}$ selama 6 jam lalu dibekukan kemudian diaduk dan dibekukan kembali sampai menghasilkan es krim probiotik.

\section{HASIL DAN PEMBAHASAN}

Hasil analisis variabel total bakteri asam laktat (BAL), $\mathrm{pH}$, dan overrun es krim disajikan pada Tabel 1.

\section{Total BAL es krim probiotik}

Data rataan hasil analisis total bakteri asam laktat pada Tabel 1 menunjukkan bahwa rataan total bakteri asam laktat yang diperoleh pada es krim dengan perlakuan level starter yang berbeda menunjukkan total BAL yang beragam berkisar antara 1,49 sampai 7,08 (Log-cfu/ml). Nilai rataan total bakteri asam laktat pada es krim probiotik tertinggi diperoleh pada perlakuan A4 dengan penggunaan level starter $9 \%$.
Sedangkan total bakteri asam laktat terendah dihasilkan dari penggunaan level starter 0\% (kontrol).

Berdasarkan hasil analisis sidik ragam menunjukkan bahwa perlakuan dengan level starter $0 \%, 3 \%, 6 \%$ dan $9 \%$ memberikan pengaruh yang berbeda sangat nyata $(\mathrm{P}<0,01)$ terhadap total bakteri asam laktat es krim yang dihasilkan.

Hasil uji lanjut beda nyata jujur menunjukkan bahwa total bakteri asam laktat es krim pada penggunaan 0\% sebagai kontrol berbeda nyata lebih rendah dari penggunaan level starter 3\%,6\%, dan 9\%. Selanjutnya penggunaan level starter $3 \%$ berbeda nyata lebih rendah dari penggunaan level starter $6 \%$ dan $9 \%$. Kemudian penggunaan level starter 6\% berbeda nyata lebih tinggi dari penggunaan level 3\% tapi berbeda nyata lebih rendah dari penggunaan level starter $9 \%$. Sedangkan penggunaan level starter 9\% berbeda nyata lebih tinggi dari penggunaan level starter 3\%, dan $6 \%$.

Dari data tersebut dapat dijelaskan bahwa total bakteri asam laktat dipengaruhi oleh penggunaan level starter yang digunakan. Total bakteri asam laktat yang meningkat seiring dengan bertambahnya level starter yang digunakan. Hal tersebut sesuai dengan 
Tabel 1. Rataan Karakteristik Es Krim

\begin{tabular}{lcccc}
\hline \multirow{2}{*}{ Variabel } & \multicolumn{4}{c}{ Level starter $( \pm$ Sd $)$} \\
\cline { 2 - 5 } & $0 \%$ & $3 \%$ & $6 \%$ & $9 \%$ \\
\hline Total BAL $(\mathrm{cfu} / \mathrm{ml})$ & $1.49 \pm 0.06^{\mathrm{a}}$ & $6.09 \pm 0.02^{\mathrm{b}}$ & $6.97 \pm 0.01^{\mathrm{c}}$ & $7.08 \pm 0.04^{\mathrm{d}}$ \\
Nilai pH & $6.67 \pm 0.03^{\mathrm{d}}$ & $5.34 \pm 0.16^{\mathrm{bc}}$ & $5.32 \pm 0.12^{\mathrm{b}}$ & $5.24 \pm 0.14^{\mathrm{a}}$ \\
Overrun (\%) & $25.62 \pm 0.29^{\mathrm{a}}$ & $28.09 \pm 0.08^{\mathrm{b}}$ & $30.39 \pm 0.40^{\mathrm{c}}$ & $31.47 \pm 0.38^{\mathrm{d}}$
\end{tabular}

Keterangan: Superskrip yang berbeda pada baris yang sama menunjukkan perbedaan yang nyata $(\mathrm{P}<0,01), \mathrm{Sd}=$ standard deviasi

pendapat Yelnetty (2008) dan Mulyani, et al. (2008) bahwa meningkatnya konsentarasi starter berarti peningkatan jumlah bakteri pada media dan pada kondisi yang ideal, peningkatan bakteri akan diikuti dengan peningkatan aktivitas serta perkembangbiakan bakteri.

Total bakteri asam laktat dalam es krim probiotik yang dihasilkan adalah $10^{6}-10^{7} \mathrm{CFU} / \mathrm{ml}$. Menurut Tannock (1999), salah satu syarat produk probiotik adalah mengandung sel mikroba hidup sebesar $10^{6}-10^{8} \mathrm{CFU} / \mathrm{ml}$. Oleh karena itu, produk es krim probiotik yang dihasilkan dapat memenuhi syarat produk probiotik. Berdasarkan hasil dan pembahasan total BAL yang dihasilkan pada es krim probiotik diketahui bahwa penggunaan starter probiotik pada level 9\% merupakan es krim yang terbaik.

\section{Nilai pH es krim es krim probiotik}

Data rataan hasil analisis $\mathrm{pH}$ pada Tabel 1 menunjukkan bahwa rataan nilai $\mathrm{pH}$ menggunakan level starter yang berbeda menghasilkan nilai yang beragam berkisar antara 5,24 sampai 5,67. Nilai pH es krim dengan penggunaan level starter 9\% menghasilkan nilai $\mathrm{pH}$ terendah yakni 5,24, sedangkan penggunaan level starter $0 \%$ (kontrol) menghasilkan nilai $\mathrm{pH}$ es krim yang tinggi $(6,67)$

Berdasarkan hasil analisis sidik ragam menunjukkan bahwa penggunaan level starter $0 \%, 3 \%, 6 \%$, dan $9 \%$ pada pembuatan es krim berpengaruh sangat nyata ( $\mathrm{P}<0,01)$ terhadap nilai $\mathrm{pH}$ es krim yang dihasilkan.

Hasil uji lanjut menggunakan uji beda nyata jujur menunjukkan bahwa nilai $\mathrm{pH}$ es krim probiotik dengan penggunaan level starter $0 \%$ sebagai kontrol berbeda 
nyata lebih tinggi dari penggunaan level starter 3\%, 6\%, dan 9\%. Sedangkan penggunaan level starter 3\% tidak berbeda nyata dengan penggunaan level starter $6 \%$ dan level starter $9 \%$.

Nilai pH es krim yang dihasilkan dengan menambahkan BAL menunjukkan bahwa penggunaan level starter 3\%, 6\%, dan $9 \%$ menghasilkan $\mathrm{pH}$ yang lebih rendah $(5,24 ; 5,32 ; 5,34)$ dibandingkan dengan nilai $\mathrm{pH}$ yang menggunakan level starter $0 \%$ atau kontrol $(6,67)$. Menurut Arbuckle (1986), adonan es krim yang normal memiliki nilai $\mathrm{pH}$ sebesar 6.30. Nilai pH es krim yang dihasilkan lebih rendah dari pada es krim kontrol hal ini disebabkan dengan penambahan starter BAL yang akan merombak laktosa dalam susu menjadi asam laktat. Semakin meningkatnya jumlah bakteri asam laktat yang menggunakan laktosa, semakin banyak sumber gula yang dapat dimetabolisir maka semakin banyak pula asam-asam organik yang dihasilkan sehingga secara otomatis $\mathrm{pH}$ juga akan semakin rendah. BAL juga menghasilkan enzim lactase. Enzim laktase dihasilkan karena adanya aktivitas Streptococcus thermophilus (Susilorini dan Sawitri, 2006). Berdasarkan hasil dan pembahasan, nilai $\mathrm{pH}$ yang dihasilkan pada es krim probiotik diketahui bahwa penggunaan starter probiotik pada level 9\% merupakan es krim yang terbaik.

\section{Nilai Overrun es krim probiotik}

Data rataan hasil analisis overrun es krim yang dihasilkan berkisar antara 25,62 - 31,47. Nilai rataan overrun yang tertinggi diperoleh pada penggunaan level starter $9 \%$ sedangkan nilai overrun terendah diperoleh pada pengggunaan level starter $0 \%$ (kontrol) Berdasarkan hasil analisis sidik ragam menunjukkan bahwa perlakuan level starter yang berbeda memberikan pengaruh yang berbeda sangat nyata $(\mathrm{P}<0.01)$ terhadap nilai overrun es krim.

Berdasarkaan hasil uji lanjut beda nyata jujur menunjukkan bahwa nilai overrun es krim pada penggunaan 3\% tidak berbeda nyata dengan penggunaan level starter $0 \%$, tapi berbeda nyata lebih rendah dari penggunaan level starter $6 \%$ dan 9\%. Selanjutnya penggunaan level starter $6 \%$ berbeda nyata lebih tinggi dari penggunaan level starter $0 \%$ dan 3\%, tapi berbeda nyata lebih rendah dari penggunaan level starter 9\%. Kemudian penggunaan starter $9 \%$ berbeda nyata lebih tinggi dari penggunaan level starter $0 \%$, $3 \%$, dan $6 \%$.

Overrun memiliki peranan yang penting dalam industri es krim. Pada umumnya, es krim dijual berdasarkan satuan volume sehingga semakin tinggi overrun akan memberikan keuntungan yang lebih besar bagi produsen. 
Nilai overrun yang terlalu rendah mengakibatkan tekstur es krim menjadi terlalu keras sehingga dapat menurunkan palatabilitas. Nilai overrun yang baik untuk produk es krim berkisar antara $28 \%$ - 30\% (Marshall dan Arbuckle, 2000). Es krim dengan penggunaan level starter 9\% menghasilkan nilai overrun tertinggi yaitu $32,4 \%$, ini kemungkinan di sebabkan karena penambahan BAL didalamnya, namun masih perlu untuk diuji lebih lanjut karena belum adanya literatur penunjang. Berdasarkan hasil dan pembahasan nilai overrun yang terbaik diperoleh pada es krim probiotik dengan penggunaan level starter 6\%. Berdasarkan hasil dan pembahasan nilai overrun yang dihasilkan pada es krim probiotik diketahui bahwa penggunaan starter probiotik pada level $6 \%$ merupakan es krim yang terbaik.

\section{KESIMPULAN}

Berdasarkan hasil analisa data total bakteri asam laktat (BAL), $\mathrm{pH}$ dan overrun dari variabel dalam penelitian ini disimpulkan bahwa es krim menggunakan starter bakteri probiotik $S$. thermophilus dan $L$. acidophilus sampai level $9 \%$ menghasilkan karakteristik es krim yang baik.

\section{Saran}

Es krim yang diteliti ini menggunakan bakteri probiotik, maka perlu penelitian lanjutan untuk melihat nilai kesehatan yang dihasilkan dengan melakukan pengujian secara biologis.

\section{DAFTAR PUSTAKA}

Arbuckle, W.S. 1986. Ice Cream. The AVI Publishing Company, Inc., Westport, Connecticut.

Chen, M. J and K.N. Chen. 2007. Applications of Probiotic Encapsulation in Dairy Products. In: Lakkis, Jamileh M. (Ed.), Encapsulation and Controlled Release Technologies in Food Systems. Wiley-Blackwell. USA. Pp 83-107.

Fuller, R. 1999. Probiotics for farm animals. Journal Horizon Scientific Press. Hal 15-22.

Gueimonde, $\mathrm{M}$ and Clara de Los R. Gavilan. 2009. Detection and Enumeration Of Gastrointestinal Microorganisms In Hand Book Of Probiotics and Prebiotics. John Wiley and Sons In Publication. USA

Marshall, R.T. and W.S. Arbuckle. 2000. Ice Cream. 5th Edition. Aspen Publisher, Inc., Gaithersburg, Maryland.

Mulyani, S., A.M. Legowo dan A.A. Mahanani. 2008. Viabilitas bakteri asam laktat, keasaman dan waktu pelelehan es krim probiotik menggunakan starter Lactobacillus casei dan Bifidobacterium bifidum. J.Indon.trop.anim.agric. 33 (2): 120-125 
Sofos, J.N. 1993. Mini review current Microbiological Consideration in Food Preservation. International. $J$. Food Microbial. 19:87-108

Steel, R.G.D dan J.H. Torrie. 1991. Prinsip dan Prosedur Statistika. Gramedia Pustaka Utama, Jakarta

Susilorini, T.E. dan M.E. Sawitri. 2007. Produk Olahan Susu. Penebar Swadaya. Yogyakarta.

Tannock, G.W. 1999. Probiotics : A Critical Review. Horizon Scientific Press, Norfolk, England.

Yelnetty, A. 2008. Perbedaan kosentrasi starter yang digunakan terhadap kualitas es krim probiotik ubi jalar. Laporan penelitian. (tidak dipublikasi)

Yelnetty, A .2010. Kualitas es krim probiotik dari ubi jalar (Ipomea batatas, L) menggunakan Streptococcus thermophilus, Lactobacillus acidophilus, Lactobacillus rhamnosus dan Bifidobacterium logum. J. Ilmiah Vol 10(1): 20-27 